\title{
THE NEED FOR A COMPETENCIES' ASSESSMENT FRAMEWORK FOR THE MALAYSIAN CONSTRUCTION PROJECT MANAGERS
}

\author{
Au Chee Moon ${ }^{1}$, Saipol Bari Abd-Karim², Mohd Suhaimi Mohd Danuri ${ }^{3}$ \\ ${ }^{1,2,3}$ Centre for Building, Construction and Tropical Architecture (BuCTA), Faculty of Built Environment, \\ University of Malaya, 50603 Kuala Lumpur, Malaysia
}

Corresponding author: saipolbari@um.edu.my

\begin{abstract}
For decades, as a developing country, construction industry remains as one of the largest and most important industries in Malaysia especially in terms of job creation. However, project failures in terms of project delay and cost overrun are observed more severe than the global average. While there are many reasons that may contribute to these problems, but recent studies carried out globally by the well-known researchers in project management have found that the competency of project manager, being one of the most important persons from initiating, to closing of the project, is one of the most crucial factor affecting project success. Many developed nations have come out with their project management assessment and certification standards, in order to train, assess, and certify the qualified project managers that are equipped with the necessary and required competencies and skills, but there is an absence of project manager's competencies assessment and certification standards in Malaysia until to date. This paper presents the literature review that have been carried out on the need for a competencies assessment framework for the Malaysian construction project managers.
\end{abstract}

Keywords : assessment, competency, construction, project manager, project success.

\section{INTRODUCTION}

This literature review paper will provide the reader with some insight of the nature and the problems faced by the construction industry, and Malaysian construction industry in particular. This is followed by the definition of project management, recent studies on Project Managers' competencies, which is the latest and most actively investigated topic that have been zoomed in as one of the most significant factors affecting project and project management success, will be outlined. The needs and benefits of certification will be discussed.

\section{METHODOLOGY OF LITERATURE REVIEW}

Literature review is the documentation of a comprehensive review of the published and unpublished works from secondary sources of data, with the purpose to identify and highlight the important variables, and to document the significant findings from earlier researches in the area of specific interest to the researcher. This will later serve as the foundation of which theoretical framework for the current study can be built on and the hypotheses developed (Sekaran, 2003).

This documentation is important for the following reasons:

1) That the researcher is knowledgeable about the problem area,

2) In order for the theoretical framework to be structured on previous studies and will add to the solid foundation of the existing knowledge. 
As recommended by Bauer and Bakkalbasi (2005) that researchers should consult Google Scholar in addition to the conventional Web of Science or Scopus for references, especially for relatively recent articles, authors or subject areas, this literature review has utilized all the above to search for published and unpublished journal articles, conference papers and proceedings, books, thesis and dissertations that are related to project management certifications and standards, the comparisons of PM standards, its benefits and effectiveness, major causes of delay and cost overruns for construction projects internationally and locally, its critical success factors (CSFs), PM competencies and etc.

\section{CONSTRUCTION INDUSTRY}

Construction industry, is known as one of the largest, complex and most people-intensive sectors. However, construction industry remained one of the most highly criticised sectors, especially with regards to its employment practices (Dainty, Green, \& Bagilhole, 2007), for its failure to adopt progressive human resource (HR) practices and operating in a fragmented, project-based environment highly reliant on subcontracting (Raja, Green, Leiringer, Dainty, \& Johnstone, 2013). The industry is a labour intensive and low-tech sector; most often resulted in people being the most expensive resource deployed (Loosemore, Dainty, \& Lingard, 2003). Nevertheless, care for the workforce is somehow often neglected, and people treated as one of the secondary aspects of the construction process and a cost to be minimized with low priority (Raja et al., 2013).

Diverse group of people with different background, expertise, and often different behaviour and working styles are brought together for a short duration, but expected to rapidly establish cooperative working relationship, to deliver projects that complexity is evermore increasing and under evermore stringent time and cost constraints (Dainty et al., 2007), is best to describe the nature of the working environment in construction industry. In addition, the industry is notoriously well-known for its 4D which stands for "Difficult", "Dangerous", "Dirty" and "Demeaning" working environment (Hamid, Singh, \& Jamadi, 2013), besides the culture of high workload, time pressure, cost pressure, poor work-life balance with long working hours, low job satisfaction, job insecurity, and heavy responsibility especially to the key personnel.

Construction industry is also amongst the industries that facing the skills shortage the most in the US (Cappelli, 2014). The problem of skill shortage in both the number and the skills they possess is commonly faced by the construction industry in the world. Coupled with the competitive tendering of most construction projects, this skill shortage will make organizations difficult to produce high-quality products within the desired budgetary and time constraints.

\section{Malaysian Construction Industry}

Malaysian construction industry (MCI), in addition to the similar general situation mentioned above, has it own's set of problems and unique situation. Although MCI only contributes 4.2\% to the national GDP at RM43.11 billion in year 2014, RM46.63 billion or 4.5\% of national GDP in year 2015, and RM50.09 billion or 4.5\% of national GDP in year 2016 (Central Bank, 2017), it remains as one of the largest and most important industry in terms of job creation. It engaged more than 1.278 million people representing about $9.23 \%$ of total workforce in year $2014,1.31$ million people representing $9.31 \%$ of total workforce in year 2015 , and 1.262 million people representing $8.9 \%$ in 2016, according to the latest Bank Negara 2016 Annual Report (Central Bank, 2017). It has registered remarkable growth rate at $11.6 \%$ in year 2014 against the overall economy growth rate of $6.0 \%$, and continued to grow at $8.2 \%$ in year 2015, and 7.4\% in year 2016 (Central Bank, 2017), as shown in Figure 1. Projects awarded in year 2015 was RM141 billion, and increased to RM229 billion in year 2016, with $77.8 \%$ coming from private sector, and over RM40.1 billion worth of oversea projects were secured on the same year ((CIDB), 2017). In the Malaysia Budget 2018, RM46 billion has been allocated for Development Expenditure in year 2018 which is expected to continue stimulate the construction industry directly and the supporting industries indirectly (Ministry of Finance, 2017). 


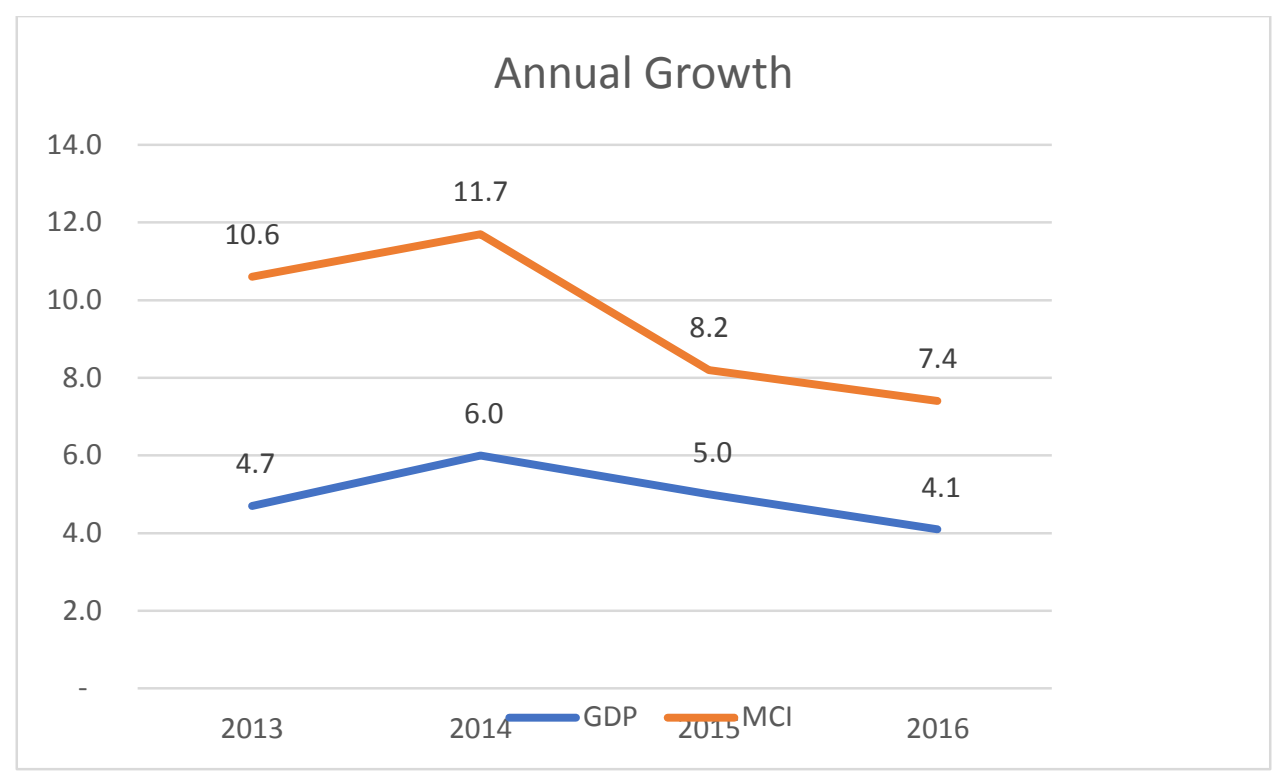

Figure 1: Annual Growth Rate of Malaysian Construction Industry against Malaysian GDP Source: (CIDB, 2017)

However, Malaysian Construction Industry (MCI) is always plagued by the severe problem of time and cost overrun (Ismail, Memon, \& Abdul Rahman, 2013). This problem apparently was observed more severe in Malaysia, where a study conducted by Endut, Shehu, Akintoye, and Jaafar (2009) as cited in Ismail et al. (2013) revealed that 79.5\% of the 308 projects investigated from public sector experienced delay. And according to Abdul Rahman, Memon, Nagapan, Imran Latif, and Abdul Azis (2012), their study shows that a shocking 92\% of the projects in Central and Southern Regions of Peninsular Malaysia suffered time overrun, and $89 \%$ of the projects experienced cost overrun. The latest example of project delayed and incurred cost overrun in Malaysia was the Kuala Lumpur International Airport 2 (known as KLIA2) project, where the project was delayed for almost 33 months, originally targeted to open in September 2011 but eventually opened in May 2014, and incurred a huge cost overrun from original RM1.6 billion to final cost of RM4 billion (Ismail, 2014; Ismail et al., 2013; Nie, 2013; Ullah, Abdullah, \& Nagapan, 2016). Another well-known project was the Malaysia External Trade Development Corporation (MATRADE) building project that was delayed for 9 years and a $70 \%$ cost overrun (Ismail, 2014). These findings and examples have shown that time and cost overrun have been very serious issues faced by the Malaysian Construction Industry and tarnishing the image of our profession, as no other professions allow such a high rate of failure in term of professional performance and delivery, besides incurring high wastages either wasting tax payers' money for public projects and increased the cost of development which will be eventually borne by the consumers or purchasers for private projects.

\section{Main Causes of Project Delay and Cost Overrun}

As every project is unique by itself whether because of its design, functionality or location, thus having their own sets of problems or reasons of delays. According to Sambasivan and Soon (2007), some post-mortem of delayed projects attributed the most critical delays factors to

- incomplete design documents by consultant,

- slow in response on clarification or approval by consultant,

- frequent change of scopes by owner,

- interference by owner,

- inexperience or incompetent contractor,

- poor planning and execution by contractor,

- $\quad$ shortage of materials,

- delay in material delivery by vendors,

- slow payment or cash flow problem, or

- $\quad$ severe weather condition at job site. 
In their study, Sambasivan and Soon (2007) found out that the top 3 most important causes of delay perceived by projects' clients, consultants and contractors were:

1) poor planning,

2) substandard site management, and

3) insufficient experience by contractors.

In the similar study on construction projects in Malaysia, Abdul Rahman et al. (2012) concluded that project management, contract administration, as well as contractors' site management, were amongst the top ranking major causes of time and cost overrun. Meanwhile, Abdul Rahman, Memon, and Abd. Karim (2013) identified three significant factors that leads to budgets in large contruction projects in Malaysia being exceeded, namely, instability of material prices and cash flow whih relates to contracor's site management and financial problems experienced by contractors which is external problem and beyond control. These findings indicate the need of urgent attention to improve contractors' undertaking to attain significant cost performance so as to stay away from catastrophe (Abdul Rahman et al., 2013). This was echoed by a study carried out by Michael, Deepak, Venishri, and Siow (2014) which deduced that human related factors such as competence, commitment, and communication among project stakeholders should be given more attention, and more time should be allocated for training on project management.

These have further strengthened the findings of an earlier study conducted by Yong and Mustafa (2011) that human factors should be given more emphasis in effort to heighten the success rate of future construction project implementation. Esa, Abdul Samad, and Alias (2014) also found that the the aforementioned competency of a project manager is a critical element affecting project success that, eventually, will indirectly improve the organizational performance. It was also observed that successful construction organizations nowadays concentrate on making certain that their project managers obtain the core competencies necessary to succeed in performing their duty (Esa et al., 2014). Furthermore, these studies have also confirmed the earlier findings from the international studies that; human factor, especially pointing to the competencies of the most important persons in any projects, i.e. the project managers, is of paramount importance and a vital factor in projects success (APM, 2014; BMG, 2014; Crawford, 2000, 2013; Edum-Fotwe \& McCaffer, 2000; Endut et al., 2009; P. Morris, 2013; Nahod, Vukomanović, \& Radujković, 2013; Sommerville, Craig, \& Hendry, 2010).

One of the weak points identified in Malaysian construction industry is the integration breakdown between the design process and the construction production process (Mustafa Kamal, Haron, Md Ulang, \& Baharun, 2012). Ibrahim, Roy, Ahmed, and Imtiaz (2010) describe the disparity between the consultants who plan and design, and the implemention team who execute construction projects could be another reason for the situation. This indicates that Malaysian construction industry is still highly fragmented, with clear disconnection between the parties involved in the project. This high failure rate in both time and cost overrun problem faced by the Malaysian Construction Industry has seriously tarnished the reputation of the industry, and have caused very damaging impact to the confidence level of the foreign investors toward Malaysia. Besides, huge amount of taxpayers' money for public projects have been wasted (Koops, Bosch-Rekveldt, Coman, Hertogh, \& Bakker, 2016; Wu, 2011) and higher cost of development were caused by this. The root-cause of the problem therefore must be investigated and subsequently corrected. In order to face the challenges of the globalization, Malaysian Construction Industry must improve to achieve higher project success rate, compete through constant improvement in productivity, with more value-added operations \& enhanced quality (Ibrahim et al., 2010). Higher project success rate helps to improve organizational performance as well as national competitiveness $(\mathrm{Wu}, 2011)$.

\section{Project Management}

Various project management institutions have varying definitions for project management. For example, the International Project Management Association (IPMA) indicates that project management requires the utilization of both hard and soft components of the projects; the tools and techniques which are the hard components and also the competencies which are the soft components; in achieving the project goals (IPMA, 2015). Meanwhile, the Project Management Association of Japan (PMAJ) highlights on the soft components of project requirement, that is the professional capability in delivering the projects with due diligence, along with a reliable project team and assisted by the hard components of the project (PMAJ, 2005).

Although these definitions may have sounded very general, project management is definitely one of the most intellectually as well as physically challenging professions. From technical proficiency, intellectual competencies, 
emotional competencies, managerial competencies, contextual or perspective competencies and so forth, a wide range of capabilities are requires for effective project management (Slevin \& Pinto, 2007). Empirically, there are four conditions necessary for project success and are listed as follows (Atencio, 2013):

1) A criteria for project success should be established at the early stage of project with the project stakeholders, and be reviewed regularly for the entire duration of the project.

2) An amalgamated working affiliation between the owner and project manager should be established and upheld, for which project is viewed as a partnership.

3) An authorization given to the project manager to have the flexibility and to work closely with the owner in dealing with uncertainty and providing advice on how best to achieve project success.

4) An active participation of project owner that is concerned for the performance of the project.

Atencio (2013) highlighted that there are four up-and-coming perspectives of project success and are listed as follows:

- Project management is acknolweged as a strategic asset by the organization.

- Evaluation of project managers' performance should be broader rather than the conventional budget, schedule and scope, with flexibility in manoeuvring.

- Active invovlment and demonstration of strong interest by the the project sponsors/clients.

- Greater emphasis on the competency and leadership style of the project manager as contributories.

Lechler (2000) discovered that the trend that recognizes the "human" side of project management as a pivotal factor to project success has been growing. Additionally, such a human side, or the people side of project management has also been highlighted many authors (Nixon, Harrington, \& Parker, 2012; Postma, 2016; Scott-Young \& Samson, 2004; Slevin \& Pinto, 2007; Winch, 2010). Meanwhile, project industry once focused primarily on the project methodology, tools and techniques (PMTT), instead of the individual project manager. As a result, organizations, clients, and key project stakeholders were having the notion that with the right project management software, cookiecutter methodology and templates, anyone could deliver a project successfully (Atencio, 2013). Muller and Turner (2010) in their study on chronological development of leadership theories also found that project manager's match of personality and project type have significant influence to project success, instead of just the PMTT used.

\section{Critical Success Factors (CSF)}

Extensive studies have been carried out on Critical Success Factors (CSF) for project management. According to APM BOK (APM, 2012), success factors are "management practices that, when implemented, will increase the likelihood of success of a project. Their presence in a project does not in itself guarantee success, but their absence will contribute to its failure" (APM, 2012). Some of the high-level success factors include:

- defining clear goals and objections,

- maintaining a focus on business value,

- implementing a proper governance structure,

- $\quad$ ensuring senior management commitment,

- providing timely and clear communication.

Table 1 below listed some of the CSFs and their detail explanation:

Table 1. Critical Success Factors defined by Association of Project Management (APM) Sourced from (APM, 2012)

\begin{tabular}{|c|c|}
\hline Critical Success Factors, CSF & Detail Explanation \\
\hline \multirow{3}{*}{ Competent project teams } & $\begin{array}{l}\text { Project professionals heading up or forming a core team are fully } \\
\text { competent }\end{array}$ \\
\hline & Other team members are also fully competent in their roles \\
\hline & $\begin{array}{l}\text { The project team engages in positive behaviours which encourage } \\
\text { success }\end{array}$ \\
\hline
\end{tabular}




\begin{tabular}{|c|c|}
\hline \multirow{4}{*}{ Effective governance } & The project has strong, clearly identified leadership \\
\hline & $\begin{array}{l}\text { The project has clarity as to how authority is distributed below the } \\
\text { overall leadership level }\end{array}$ \\
\hline & The project has clear reporting lines \\
\hline & $\begin{array}{l}\text { The project has clear and regular communications between all } \\
\text { parties }\end{array}$ \\
\hline \multirow[b]{2}{*}{ Proven methods and tools } & Good practice project management techniques are applied \\
\hline & $\begin{array}{l}\text { Management tools, methods and techniques are applied in a way } \\
\text { which maintains an effective balance between flexibility and } \\
\text { robustness }\end{array}$ \\
\hline \multirow{3}{*}{ Secure funding } & $\begin{array}{l}\text { The project has a secure funding base at the point where the decision } \\
\text { to start is taken }\end{array}$ \\
\hline & Any needs for contingency funding are recognised from the start \\
\hline & $\begin{array}{l}\text { Tight control of budgets is in place to ensure that the value of } \\
\text { available funding is maximised }\end{array}$ \\
\hline \multirow{4}{*}{ Goals and objectives } & $\begin{array}{l}\text { The overall goal of the project is clearly specified and recognised by } \\
\text { all stakeholders involved in the project }\end{array}$ \\
\hline & $\begin{array}{l}\text { Subsidiary objectives are clearly specified and recognised by all } \\
\text { stakeholders who need to be aware of them }\end{array}$ \\
\hline & Overall goals and subsidiary objectives are not in conflict \\
\hline & $\begin{array}{l}\text { Project leadership has a clear vision of what project outcomes should } \\
\text { be, maintains continuity of vision, and disseminates this vision to all } \\
\text { involved in project delivery }\end{array}$ \\
\hline \multirow{4}{*}{ End users and operators } & $\begin{array}{l}\text { 'End users and operators' refer to individual(s) or organisation(s) } \\
\text { which use or operate the 'outcome' of a project. This could include, } \\
\text { for example, the managers and staff of a new manufacturing facility, } \\
\text { the office workers who use a newly-introduced software system, or } \\
\text { the residents of a new housing development. }\end{array}$ \\
\hline & $\begin{array}{l}\text { End users or operators are engaged in the design and progress of the } \\
\text { project }\end{array}$ \\
\hline & $\begin{array}{l}\text { Where end users or operators are reluctant to engage, the project } \\
\text { team has the skills and techniques to increase and improve the } \\
\text { quality of their engagement }\end{array}$ \\
\hline & $\begin{array}{l}\text { End users or operators are able and enabled to take on what the } \\
\text { project has produced effectively and efficiently }\end{array}$ \\
\hline \multirow{3}{*}{ Commitment to project success } & $\begin{array}{l}\text { All parties involved in the project are and remain committed to the } \\
\text { project's success }\end{array}$ \\
\hline & $\begin{array}{l}\text { Where there is any lack of commitment this is clearly recognised and } \\
\text { dealt with }\end{array}$ \\
\hline & $\begin{array}{l}\text { Project leadership, particularly, has and maintains commitment and } \\
\text { has the skills and resources to inspire commitment in others }\end{array}$ \\
\hline \multirow[t]{2}{*}{ Supportive organisation } & $\begin{array}{l}\text { 'Organisations' as used here refer to the employing organisation, } \\
\text { although that can sometimes mean more than one (in the case of very } \\
\text { large collaborative projects). }\end{array}$ \\
\hline & $\begin{array}{l}\text { The environment in which the project operates is project- friendly } \\
\text { rather than project- hostile }\end{array}$ \\
\hline
\end{tabular}




\begin{tabular}{|c|c|}
\hline & The organisation provides embedded support for project activity \\
\hline & $\begin{array}{l}\text { The project team has the influencing skills to engage with necessary } \\
\text { internal and external support }\end{array}$ \\
\hline & $\begin{array}{l}\text { The project environment provides sufficient resourcing (including } \\
\text { financing) and access to stakeholders }\end{array}$ \\
\hline & $\begin{array}{l}\text { 'Standards' here refers to the regulatory environment and } \\
\text { appropriate standardised methods and tools. }\end{array}$ \\
\hline Appropriate standards & Quality standards are actively used to drive quality of outputs. \\
\hline & $\begin{array}{l}\text { Adherence to other standards is regularly monitored in order to } \\
\text { ensure delivery is to best practice levels. }\end{array}$ \\
\hline Capable sponsors & $\begin{array}{l}\text { 'Sponsors' here refers to the individual(s) or organisation(s) which } \\
\text { have the ultimate responsibility for the project's goals and for its } \\
\text { creation and existence. In the case of an internal, within- } \\
\text { organisation, project, the 'sponsor' could, for example, be a } \\
\text { company's Board or a committee within a public body. Where the } \\
\text { project is an external one delivered on behalf of another } \\
\text { organisation, the 'sponsor' may simply be the client. }\end{array}$ \\
\hline & The project has named and active sponsors \\
\hline & $\begin{array}{l}\text { The project has sponsors who have ultimate responsibility and } \\
\text { accountability and are effective }\end{array}$ \\
\hline & $\begin{array}{l}\text { The project has sponsors who stay in role for the life-cycle of the } \\
\text { project }\end{array}$ \\
\hline Aligned supply chain & $\begin{array}{l}\text { All direct and indirect suppliers are aware of project needs, } \\
\text { schedules, and quality standards }\end{array}$ \\
\hline & Higher and lower tiers of supply chains are co-ordinated \\
\hline & Pre-project planning is thorough and considered \\
\hline & The first, start-off, phase of the project is effective \\
\hline Project planning and review & $\begin{array}{l}\text { There is regular and careful progress (time, scope, cost) monitoring } \\
\text { and review throughout the project }\end{array}$ \\
\hline & The project has realistic time schedules \\
\hline & $\begin{array}{l}\text { The project has active risk management and is flexible enough to } \\
\text { respond to unforeseen hazards and opportunities }\end{array}$ \\
\hline & Post-project review is undertaken to learn lessons for the future \\
\hline
\end{tabular}

In one of the studies carried out on the Critical Success Factors (CSFs) required in Malaysia, Yong and Mustafa (2011) recommends that it is significant to refine the human related factors such as commitment, competency, and communication, in improving project success rate. Echo with the similar findings, Michael et al. (2014) advised that human related factors i.e. commitment, competency and communication amongst project stakeholders should be paid more attention, and that more time should be allocated for training in improvement these project management skills. Besides the technical competencies, factors from the project management perspective i.e. from the processes involved, and the influence of human factors such as attitudes, mentality, skills and behaviour should be improved in order to enhance the project success rate (Hamzah, Khoiry, Arshad, Badaruzzaman, \& Tawil, 2012).

Yong and Mustafa (2011), in their study on the clients, consultants and contractors perception of CSFs for construction projects in Malaysia, explained that CSFs are not a fixed set of key indicators that can be used in all industries, but are the specific aspects of great importance to a particular industry, at a certain moment, that 
neccesitate exclusive and distinct circumstances, which must be assessed through flexible and subjective information. Another aspect to consider is that as in any projects would have in general three parties involved, i.e. 1) the project owner or client, 2) the consultant that consists of architects, engineers, quantity surveyors, interior designers etc, and the 3 ) contractors; each party would have different perceptions on most important CSFs in project success. Table 1 shows the findings from Yong and Mustafa (2011) in their study on CSFs in Malaysia.

Table 1: Clients consultants and contractors perception of CSFs for construction projects in Malaysia (Source: (Yong \& Mustafa, 2011))

\begin{tabular}{llllll}
\hline Rank & $\begin{array}{l}\text { Based on Client's } \\
\text { Architect-in-charge }\end{array}$ & PM \& $\begin{array}{l}\text { Based on } \\
\text { Constultant }\end{array}$ & Project & Based on Project Contractor \\
\hline 1 & Competency & Competency & Control over subcontractors \\
\hline 2 & Commitment & $\begin{array}{l}\text { Cooperation in solving } \\
\text { problems }\end{array}$ & $\begin{array}{l}\text { Adequacy of design details \& } \\
\text { specifications }\end{array}$ & \\
\hline 3 & $\begin{array}{l}\text { Early and constant } \\
\text { involvement in the project } \\
\text { development }\end{array}$ & Commitment & Skilful workers & \\
& & & & & \\
\end{tabular}

Many researchers agreed that the project manager's competency is a crucial factor that ensures desirable project outcomes, that eventually influence the performance of the organization. And it has been a recent trend that successfully construction organization putting more emphasis in making sure that their project managers are equipped with the ultimate competencies necessary to successfully perform their duties (Esa et al., 2014).

\section{Competency}

"Competent" originated from the Latin word 'competere', which means "to be suitable". The followings are various available competency term from the project management related professional bodies.

Table 2: Various competent terms

\begin{tabular}{|l|c|}
\hline \multicolumn{1}{|c|}{ Term or Definition } & \multicolumn{1}{|c|}{ Source } \\
\hline $\begin{array}{l}\text { Someone who is sufficiently skilled to perform a specified responsibility or } \\
\text { to fill a defined position. }\end{array}$ & (GAPPS, 2007) \\
\hline $\begin{array}{l}\text { Ability to perform the activities within an occupation or function to the } \\
\text { standard expected in employment. }\end{array}$ & (AIPM, 2010) \\
\hline $\begin{array}{l}\text { A collection of knowledge, personal attitudes, skills and relevant experience } \\
\text { needed for someone to be successful in performing his duty. }\end{array}$ & (IPMA, 2006) \\
\hline $\begin{array}{l}\text { The combination of knowledge, skill and behaviour that a person requires to } \\
\text { perform effectively in his job. }\end{array}$ & (APM, 2012) \\
\hline
\end{tabular}

Based on the study carried out by APM (2014) with 850 experienced project professionals and thought leaders across the public and private sectors, $87 \%$ of the respondents rated "Competent Project Team" as "very critical success factor", and found that "Competent Project Team" was both "important" and "present" in their recent projects carried out (APM, 2014). And in the research conducted by BMG (2014) for APM on factors in project success, BMG described that competent project professionals and capable project teams were universally regarded as sine qua non or indispensable element of successful projects.

The role of a project manager in any organization is a difficult and demanding jobs (Ahsan, Ho, \& Khan, 2013) which call for a greater comprehension of the various disciplines to be well coordinated. Hence the ultimate product is heavily relying on the capability of the project manager; thus made it crucial to appoint the competent project manager (Mantel, Meredith, Shafer, \& Sutton, 2006). The project manager manages the entire process of project from identifying project requirements, to establishing objectives, appraising the challenging demands for scope, 
cost, time and quality, adjusting to strategies and methods to the varying expectations and concerns of the stakeholders, and constant dealing with uncertainty (Ahsan et al., 2013).

Project management is a field that has always been characterized by its focus of a combination of technical components, (such as Ghantt Chart, planning and monitoring software like Primavera or Microsoft Project, earned value analysis etc) together with management and behavioural concepts. While many of these project methodology, tools and techniques (PMTT) were developed in the 1960s and 1970s, main focus has been shifted to people and teamwork at the turn of the millennium (Slevin \& Pinto, 2007). The Project Management Continuous Development (PMCD) Framework developed by US Project Management Institute (PMI) utilizes 3 competencies' dimensions of the project manager namely Knowledge, Performance, and Personal. According to the PMCD framework, a project manager ought to satisfy the elements of competencies as follows:

- Knowledge competence - project manager should acquire knowledge on the application of project management processes including the required tools and techniques to execute the project;

- Performance competence - project manager should be able to employ the knowledge competencies to achieve the project requirements; and

- Personal Competence - project manager should possess the right attitude and essence of personality attributes in performing his duties within a project environment.

The project manager must also be inspirationally brilliant (Slevin \& Pinto, 2007), enthusiastic, and at the same time be the motivating force for the team particularly during situations of deficient resources, low morale and enthusiasm, in some cases with trivial authority. It is also inherent that project managers are found to be self-motivated and that organizations are now started to focus more on selecting the individuals rather than motivating them (Slevin \& Pinto, 2007).

Cheng, Dainty, and Moore (2005) think that identifying exceptional project managers is achievable according to competency profiles, and later developed a competency-based framework for this identification of excellent project managers for the construction industry. Their research found that the behavioural competencies of excellent project managers could be identified through a holistic approach which focused on the job role, such as job task competencies associated with the project management function, and the characteristics or behavioural competencies of the project manager. Their findings suggest 12 core competencies as shown in Table 3 that form the foundation of the success of project manager performance.

Table 3: Core Competencies of Successful Project Manager

\begin{tabular}{l|l}
\multicolumn{2}{c}{$($ Source: $($ Cheng et al., 2005)) } \\
\hline No. & Core Competencies \\
\hline 1 & Achievement orientation \\
2 & Initiative \\
3 & Information seeking \\
4 & Focus on client's needs \\
5 & Impact \\
6 & Influence \\
7 & Directionality \\
8 & Team leadership \\
9 & Analytical thinking \\
10 & Conceptual thinking \\
11 & Self-control \\
12 & Flexibility \\
\hline
\end{tabular}

Cheng et al. (2005) found that although the behavioural competencies of exceptional project managers can be identified, job-task competencies were usually vastly industry-specific. Behavioural competencies of exceptional project managers are found to be more nonspecific and can be used in a variety of management positions. Together with these findings, the utilization of competencies to accomplish performance is imperative in theory as well as in practice (Ahsan et al., 2013). Chen, Chang, and Yeh (2004) found that the ability of organizations to recruit effectively play a vital role in determining their success. Further to the high complexity of project works, the immensely competitive business environment in construction industry coupled with the shortage of competent 
project managers have made the ability of organization to exert a pull on the desirable capacity essential for business sustainability. This has made the recruitment of the right project manager a major challenge for organizations (Ahsan et al., 2013). Omidvar, Jaryani, Abdul Samad, Zafarghandi, and Nasab (2011) also acknowledged that in order to survive in this highly competitive market, many organizations today are looking for "advantages" or having edge over others. And one of these "competitive advantages" is having competent project managers and a team of competent project personnel. The increase in interest of engaging and managing effectual project managers has resulted in shifting of focus from identifying which credentials are required to which skills are imperative (Ahsan et al., 2013). Muller and Turner (2010) found that critical thinking, influence, motivation and conscientiousness are important for the winning managers in all genres of projects besides the transactional leadership and transformational leadership, which are also crucial on more demanding projects.

Althouth project management is being implemented in various industries, the project manager's designation often is an accidental profession for many individuals. Most often individuals who are only equipped with certain skills and competency in a particular discipline, or managerial experience were either assigned or take up the role of project manager, without sufficient project management training and support, and without making a planned career choice - thus the accidental project manager (Ensworth, 2001). Sergio Pellegrinelli and Garagna (2010) argue that it should not be a surprise for frequent project and programme failures due to this. Pellegrinelli and Garagna (2010) pointed out that one surer and safer way of helping individuals acquire a new conception is by development processes that stimulate new perspectives and experiences. Constant support in the form of coaching and mentoring, or communities of practice have been found to increase the effectiveness of such development efforts. In order to develop their project managers and personnel skills, organizations must engage them in problem solving and decision making, as well as encouraging them to come up with new ideas in working groups. Through this learning method, project managers can enhance their communication, collaboration, and critical thinking skills (Omidvar et al., 2011). Post-project review is another effective way in advancing project managers knowledge.

\section{Project Management Certification}

Similar to most of the other professions, one of the ways to ensure only the right persons equipped with the right competencies are filled into the key project positions, or at least to filter those who are truly incompetent, besides the normal scrutinizing the curriculum vitae and interviews, would be the certification process by the creditable organization or bodies. In managing human resources, Huemann, Turner, and Keegan (2007) found out that numerous project-oriented organizations demand their prospective project managers to attain certification, which reflected that certification is widely recognized as external quality assessment for project management competency. It is also quite common that the clients solicit for certified project managers to manage their projects (Huemann et al., 2007). In the information technology (IT) industry, certification has become a necsssity in many jobs, and has become a screening tool instead of a hiring tool (Crawford \& Pollack, 2008). Conversely, Ríos-Carmenado, DíazPuente, and Martínez-Almela (2011) highlighted on the effect of the certification in project management towards employability in Spain and revealed that majority of the project management experts acknowledged that such qualifications can increase employability, and has become a professional tool that is beneficial to their career. Additionally, all the experts also affirmed that the effects of having such qualifications have gone far-off the individual gain which have also positively impacted other areas such as team work, as well as the organization as a whole (Ríos-Carmenado et al., 2011). Moreover, in an analysis conducted by Ahsan et al. (2013) on 762 job advertisements in Australia and New Zealand (55.6\% \& 44.4\% respectively) markets, found that under knowledge category, project management certification is the 2 nd most cited competency, following education $(28.61 \%)$.

\section{Project Management Standards}

As the competencies of project managers have been identified as one of the most important CSFs for project success, and thus given heavier importance progressively, many developed nations have over the years come out with their own project management assessment and certification standards, in order to train, assess, and certify the competent project managers. Table 4 illustrates the development of some established project management professional bodies and their project managers' competencies assessment standards: 
Table 4: Project management bodies of knowledge and project manager's competencies assessment standards.

\begin{tabular}{|l|l|}
\hline Project Management Institute, US (PMI) & $\begin{array}{l}1^{\text {st }} \text { PMBOK PM assessment standard published in } \\
1987\end{array}$ \\
\hline Project in Controlled Environment (PRINCE2) & $\begin{array}{l}1^{\text {st }} \text { PRINCE PM assessment standard published in } \\
1989\end{array}$ \\
\hline Association of Project Management, UK (APM) & $\begin{array}{l}1^{\text {st }} \text { APMBOK PM assessment standard published in } \\
1991\end{array}$ \\
\hline $\begin{array}{l}\text { Australian Institute of Project Management, Australia } \\
\text { (AIPM) }\end{array}$ & $1^{\text {st }}$ PM assessment standard published in 1996 \\
\hline $\begin{array}{l}\text { International Project Management Association, Europe } \\
\text { (IPMA) }\end{array}$ & $\begin{array}{l}1^{\text {st }} \text { ICB } 2.0 \text { PM assessment standard published in } \\
1999\end{array}$ \\
\hline $\begin{array}{l}\text { Project Management Association of Japan, Japan } \\
\text { (PMAJ) }\end{array}$ & $1^{\text {st }}$ P2M PM assessment standard published in 2005 \\
\hline $\begin{array}{l}\text { Global Alliance for Project Performance Standards } \\
\text { GAPPS) }\end{array}$ & $1^{\text {st }}$ GAPPS PM assessment standard published in \\
\hline $\begin{array}{l}\text { Green Project Management Global (GPM) } \\
2007\end{array}$ & $1^{\text {st }}$ GPM PM assessment standard published in 2013 \\
\hline
\end{tabular}

Project personnel are constantly investigating and identifying the related certifications and credentials in project management in enhancing their profession. As project-based work takes centre stage (Stewart, 1995), project workforce are desirous in becoming competent and to be recognized as professional. Should they are evaluated accordingly based on their skills and competencies rather than their position, (Stewart, 1995), such competencies will be exceptionally imperative to both, the individuals and the organizations (Crawford, 2007).

Project management standards are often structured to achieve the minimum in terms of quality of certification as well as standards. The standards identify those who have achieved the required criteria, yet not restraining others to practice in the profession (Crawford \& Pollack, 2008). It is therefore the similar certification instead of licensure shall be proposed for the Malaysian Construction Project Manager certification standard. It is also noted that the motivation to normalize the professions either by means of licensing or official recognition more often than not originates from inside the profession, in preference to those who consume their services (Friedman, 1962; Wolfson, Trebilcock, \& Tuohy, 1980). Generally, project management competency standards shall be considered to fall into 2 main categories; Knowledge-based or Attribute-based competency standard which are associated to what project managers are expected to know, and Performance-based or occupational competence standards which are associated to what project managers are expected to be capable of.

For example, the principal competencies that are required and expected from a project manager are the various skills related methods and tools; team and people; basic business and management; knowledge of project sponsor role; knowledge and awareness of project environment and; technical knowledge (P. W. G. Morris, 1997) as well as the ability to integrate the above mentioned skills and knowledge (Gale, 2007). Performance-based project management competency standards describe what project managers can be expected to perform in their profession, including the required knowledge to hold up these roles at an explicit level of competence. Performance-based competency standards are connected with manifestation of the skill to perform at a tolerable norm in the workplace, highlighting on threshold level more willingly than high performance competencies (Crawford \& Pollack, 2008; Heywood, Gonczi, \& Hager, 1992). Additionally, such a performance-based competency standards apprehends beyond the test of knowledge but assumes that competence is anecdotal at an inevitable tolerable standard (Gonczi, Hager, \& Athanasou, 1993).

\section{DISCUSSION}

It is found that there is a gap that not many researches have been carried out in Malaysia on the most important people of all projects, i.e. the project manager. Although some of the studies carried out on Malaysian Construction Industry (Abdul Rahman et al., 2013; Abdul Rahman et al., 2012; Esa et al., 2014; Michael et al., 2014; Sambasivan \& Soon, 2007; Yong \& Mustafa, 2011) pointed out that the competencies of project managers is one of the top ranking critical success factors and required urgent attention for improvement, but again not many studies have been done to find out further which are the competencies that are most needed to be equipped by the project manager in ensuring project success in Malaysia. In addition to the above, although various project management standards have 
been established by some of the developed nations, there is an absence of project manager's competencies assessment and certification standards in Malaysia until to date. If we practice "one size fit all" attitude, to adopt any of the above standards and start certifying project managers, and hope that what works for other countries should also works for us, should not be the best solution to our problem. Citing Toor and Ogunlana (2006), Yong and Mustafa (2011) mentioned that in order to understand the factors 'critical' to the success of the Malaysian construction project, future studies to be conducted should consider the nature and structure of the local industry, type and scale of projects, procurement procedures, local working culture, maturity of the organisation involved as well as society norms.

Knowledge-based standards such as PMBOK and APM BoK have mull over the required minimum knowledge in project management. They generally focus on the substance despite the varying depth, terminology used, format, structure and scope of topic coverage (Crawford, 2007). These standards including the PMCD Framework although arranged in different structures and format, essentially represents the necessary knowledge areas in project management, which are designed to be applicable for most projects and non-industry-specific. It means that project type, project size and its complexity, project nature, organizational and industrial specific needs, and cultural differences are not taken into account in these standards. The disadvantage of these standards, therefore, some specific or related competencies that are needed would be missed (Omidvar et al., 2011). These competencies can be described either in traditional way, giving emphasis to cost, time and scope as in PMBOK; or being a holistically process-oriented as in PRINCE2; or perhaps putting emphasize on project and organization context (Huemann et al., 2007). PRINCE2 is found to be more dogmatic by putting forward comprehensible guideline on the scope and responsibility. The standards agree that there is no formulaic approach. Therefore, the non-dogmatic nature of these standards allow freedom in selecting tools and techniques that is most suited to the particular project (Ghosh, Forrest, DiNetta, Wolfe, \& Lambert, 2012).

All the standards can be applied to a certain extent to meet the need of projects of differenct scales. Moreover, the standards agree that quality, customer satisfaction and benefit realization are the key indicators for project performance success. These standards aim to improve project success rate by finding the right balance between people and organization structure, despite the uncertainties and risks presented by the unique nature of each project. The project manager is recommended to carefully choose the right standard that meets the unique need for a project based on the intra and inter organizational aspects of the corporation (Eberle, Meyer, \& Rosen, 2011).

One of the best description on project management competency was made by Giammalvo (2014), that argued on two indisputable fundamental truths in project management competency:

1. Knowledge on project management cannot be gained solely from books but also through hands-on practice or experience.

2. Project management competency should not only be gained through objective assessments such as multiple choice questions but also through action observation and and evaluation of the results of their decisions.

\section{Industry-specific}

Most of the project management competencies standards are generic in nature, with the basis that the project management skills and techniques are applicable to all sectors and industries although the importance of various competencies differs between types of projects and industries. Zwikael (Zwikael, 2009) conducted a study on 783 project managers of diverse industries and countries discovered that scope, time, risk and human resource management are four of the Knowledge Areas (KA) from the PMBOK® Guide had the most influence on project success. These KAs were known to be sensitive to industry requirements; therefore, a general consensus in the literature is that knowledge is the basis of many of the competencies needed in successful project management, and the required knowledge for different industries may vary (Ahsan et al., 2013). This is inline with the finding by Cheng et al. (2005) that job-task competencies were highly industry-specific. However, as most projects either IT or construction related projects are dealing with technical issues and delivering output that are usually technical in nature, and as confirmed by the study conducted by Ahsan et al. (2013) that had identified the technical skill as the second most in demand competency, industry-specific competency standards may serve the needs of the relevant industry and improve project success. In view of the above, an industry-specific project management competencies standard should be considered for Malaysian Construction Industry as it should be more relevant and effective in solving the problems faced and improving the project success rate. 


\section{Sustainability Issues}

Sustainability is acknowledged as another imperative challenge by the United Nations (Glenn, Gordon, \& Florescu, 2007). The awareness of sustainability is gaining momentum, subsequent to the success of Al Gore's 'inconvenient truth', for which a paradigm shift is required, both in consumer behaviour and in corporate policies (Silvius \& Schipper, 2012). It was argued that the natural resources would be depleted should the global population and economy continuously expand (Silvius \& Schipper, 2012); in responding to the Brundtland Commission, 1987 of the United Nation.

Due to the complexity and holistic view of sustainability, it is necessary for a project manager to comprehend the integration between competencies and sustainability related to project management (Silvius \& Schipper, 2012). Additionally, Silvius and Schipper (2012) conclude six principles of sustainability: balancing or harmonizing social, environmental and economical interests, short and long term orientation, local and global orientation, consuming income, not capital, transparency and accountability and, personal values and ethics.

Project managers have been recognized by the APM (2016), IPMA (2015) as well as McKinlay (2008); Russell and Chaudhury (2008) to devote a persuasive impact on project's sustainability, and that they have to utilise such influence in making organizations more sustainable by developing their consulting skills, building expertise and significantly able to handle the project's complexity; provided that the project manager is competent to comprehend the sustainability aspects of the project (Silvius \& Schipper, 2012).

\section{Competency Framework}

Consistent with Gratton (1989), there are 3 different methods in measuring competency: the checklist, the framework and the observational approaches. Both checklists and observational methods are comparatively rudimentary techniques and seem to be employed in assessing performance. Meanwhile, the framework approach is possibly allied with relatively integrated perception of competence (Gale, 2007). Whiddett and Hollyforde (2000) as cited by Gale (2007) explain that the structural properties of an effective competence framework have to be easily understandable, be relevant, take into contemplates on accepted changes, contain distinct elements such as behavioural indicators that do not overlap, and act rational and balanced to those influenced by the use of the framework. Generally, a framework embraces competency faction that can be divided into various competencies with varying levels (Gale, 2007).

When making appointments or career progression decision, very few organisations refer systematically to established competency frameworks or rigorous research, for which it should be based on the conceptions that shape understanding and action that offer vigorous and effective approach to the selection and development of project managers (Pellegrinelli \& Garagna, 2010).

\section{Contribution}

As there are not many studies have been carried out on the competencies of construction project managers in Malaysia, this research shall contributes both on i) project management knowledge as well as its ii) practical implications.

\section{i. $\quad$ Knowledge contribution}

This study will expand the existing project management body of knowledge, particularly on the competencies of Malaysian construction project managers, which so far has been understudied locally. Project managers' competencies which has been identified as one of the most critical success factors in successful project management, have been extensively studied especially in most of the developed nations, but not yet locally. By identifying the project managers' competencies that are most needed for performing project successfully in Malaysia, tertiary education centre can further tailor their teaching material to these important competencies to meet the actual needs of the industry.

ii. Practical contribution

Hihger project failure rates in terms of time and cost overrun in Malaysian construction industry has resulted in many negative effects including high wastages, higher capital investment, waste of public fund, higher property price, interruption of planning such as late in possession of property and utilization of infrastructure, tarnished the reputation of construction practitioners and subsequently shaken the confidence of the foreign investors. This study will develop a framework for the competencies' assessment for the Malaysian construction project managers, in 
order to enable a more detail standard and assessment tool can be developed with the key industry players, that is relevant to the local scenario and meet the industry's need. This will be used as guidelines and standard to train, assess and certify qualified project managers, as part of our effort to ensure we have the very best professionals managing or working on our projects, in promoting internationally competitive workforce, that are also fit to face the ever challenging future, in order to solve the biggest problem that plaguing the industry.

\section{CONCLUSION}

An assessment and qualification processes of any bodies of knowledge or standards are indispensable in the creation and recognition of a profession. Besides the knowledge and the application of the relevant project management tools and techniques (PMTT), the soft skills or inter-personal skills, leadership and the contextual competencies are also essential in ensuring project success. In general, the common goal among all project management standards is set to achieve increasing rate of project success. However this is heavily relying on the different set of competencies; ICB stresses on technical, contextual and emotional competences, PMBOK put emphasis on process reiteration, P2M devises novelty and the configuration of project portfolio, PRINCE2 contemplates on outcome of the project in an unnatural setting, while APM put heavy emphasis on business case, design and technology management, and interpersonal skills. All these constituents need to be dealt with the right balance for effective project.

Formulating a plausible competency assessment standard is not an easy task; one has to ensure that the standard is successfully tested and consistent with the educational system prior to be considered as the so called solution for the industry. Thus any standard developed must take into account the relevancy to the time, place, cultural aspects, weaknesses and the needs of the industry. As such, a performance-based competency framework that is formulated to suit to need of the industry may addresses the weaknesses that are unique to us, and includes the elements of sustainability in project management in order to be future-proof, shall be developed.

\section{REFERENCES}

(CIDB), C. I. D. B. M. (2017, 25 - 27 October 2017). Country Report - MALAYSIA. Paper presented at the 22nd AsiaConstruct Conference, Seoul, Korea.

Abdul Rahman, I., Memon, H. A., \& Abd. Karim, A. T. (2013). Significant factors causing cost overruns in large construction projects in Malaysia. Journal of Applied Sciences, 13(2), 286-293. doi:10.3923/jas.2013.286.293

Abdul Rahman, I., Memon, H. A., Nagapan, S., Imran Latif, Q. B., \& Abdul Azis, A. A. (2012). Time and cost performance of construction projects in southern and central regions of Peninsular Malaysia. International Journal of Advances in Applied Sciences, 1(1), 45-52.

Ahsan, K., Ho, M., \& Khan, S. (2013). Recruiting Project Managers: A Comparative Analysis of Competencies and Recruitment Signals From Job Advertisements. Project Management Journal, 44(5), 36-54. doi:10.1002/pmj.21366

AIPM. (2010). AIPM Competency Standard Part C Ver 1.12 for Project Manager: Australian Institute of Project Management.

APM. (2012). APM Body Of Knowledge (6th edition). UK: Association for Project Management.

APM. (2014). Conditions for project success. Retrieved from UK: https://www.apm.org.uk/sites/default/files/Conditions\%20for\%20Project\%20Success_web_FINAL_0.pdf

APM. (2016). APM Qualifications. In U. K. Association for Project Management (Ed.): Association for Project Management, U.K.

Atencio, M. (2013). A critical success factors framework that includes leadership competencies for successful delivery of projects. Salford University, UK. Retrieved from http://usir.salford.ac.uk/30638/1/A_CRITICAL_SUCCESS_FACTORS_FRAMEWORK_THAT_INCLUDE S_LEADERSHIP_COMPETENCIES_FOR_SUCCESSFUL_DELIVERY_OF_PROJECTS_MAtencio.pdf 
Bauer, K., \& Bakkalbasi, N. (2005). An Examination of Citation Counts in a New Scholarly Communication Environment. D-Lib Magazine, 11(9).

BMG. (2014). APM Research Report: Factors in project success. Retrieved from Birmingham, UK: https://www.apm.org.uk/sites/default/files/APM\%20Success\%20report_NOV\%2014.pdf

Cappelli, P. (2014). Skill gaps, skill shortages and skill mismatches: Evidence for the US. Retrieved from http://www.nber.org/papers/w20382.pdf

Central Bank, M. (2017). Central Bank of Malaysia, B. (2017). Bank Negara 2016 Annual Report. Retrieved from http://www.bnm.gov.my/files/publication/ar/en/2016/ar2016_book.pdf

Chen, T.-Y., Chang, P.-L., \& Yeh, C.-W. (2004). A study of career needs, career development programs, job satisfaction and the turnover intentions of R\&D personnel. Career development international, 9(4), 424-437.

Cheng, M. I., Dainty, A. R., \& Moore, D. R. (2005). What makes a good project manager? Human Resource Management Journal, 15(1), 25-37.

Crawford, L. (2000, 21-24 June 2000). Profiling the Competent Project Manager. Paper presented at the Project Management Research at the Turn of the Millenium: PMI Research Conference, Paris, France.

Crawford, L. (2007). Global body of Project Management knowledge and standards, in "The Wiley Guide to Project Organizaiton \& Project Management Competencies"

Crawford, L. (2013). Competition, Comparison, Collaboration - Mapping a Pathway through Project Management Standards. Procedia - Social and Behavioral Sciences, 74, 1-9. doi:10.1016/j.sbspro.2013.03.004

Crawford, L., \& Pollack, J. (2008). Developing a basis for global reciprocity: Negotiating between the many standards for project managment. International Journal of IT Standards and Standardization Research, Volume 6(Issue 1).

Dainty, A., Green, S., \& Bagilhole, B. (2007). People and culture in construction: Taylor \& Francis.

Eberle, A., Meyer, H., \& Rosen, D. (2011). A comparison of PMI and IPMA approaches. Analysis to support the project management standard and certification system selection.

Edum-Fotwe, F. T., \& McCaffer, R. (2000). Developing project management competency - perspectives from the construction industry. International Journal of Project Management, 18, 111-124.

Endut, I., Shehu, Z., Akintoye, A., \& Jaafar, A. (2009). Cost and Time of Construction Projects in Malaysia. Paper presented at the Fifth International Conference on Construction in the 21st Century (CITC-V), Collaboration and Integration in Engineering, Management and Technology.

Esa, M., Abdul Samad, Z., \& Alias, A. (2014). Preparing project managers to achieve project success - human related factor. International journal of Research in Management \& Technology, 4(2), 104-110.

Friedman, M. (1962). Occupational licensure. Capitalism and freedom, 137.

Gale, A. (2007). Competencies: Organizational and Personal, in "The Wiley Guide to Project Organizaiton \& Project Management Competencies": John Wiley \& Sons.

GAPPS. (2007). A framework for performance based competency standards for global level 1 and 2 project managers. Retrieved from http://globalpmstandards.org/wpcontent/uploads/2014/12/GAPPS_Project_Manager_v1.1150411_A4.pdf

Ghosh, S., Forrest, D., DiNetta, T., Wolfe, B., \& Lambert, D. C. (2012). Enhance PMBOK® by Comparing it with P2M, ICB, PRINCE2, APM and Scrum Project Management Standards. PM World Today, 14(1), 1-77. 
Giammalvo, P. (2014). Project Management Credentials Compared 2014 Update. PM World Journal, Vol. III(Issue I).

Glenn, J. C., Gordon, T. J., \& Florescu, E. (2007). State of the Future. World Federation of United Nations Associations. Washington DC.

Gonczi, A., Hager, P., \& Athanasou, J. (1993). The development of competency-based assessment strategies for the professions: AGPS Canberra.

Gratton, L. (1989). Work of the manager (pp. 511-528): Wiley, New York.

Hamid, A. R. A., Singh, B., \& Jamadi, M. A. (2013). Foreign Labour Employment in Construction Project. International Journal of Scientific and Research Publications, 3(11).

Hamzah, N., Khoiry, M. A., Arshad, I., Badaruzzaman, W. H. W., \& Tawil, N. M. (2012). Identification of the causes of construction delay in Malaysia. International Journal of Civil, Environmental, Structural, Construction and Architectural Engineering, 6(12), 1063-1068.

Heywood, L., Gonczi, A., \& Hager, P. (1992). A guide to development of competency standards for professions: AGPS Canberra.

Huemann, M., Turner, R., \& Keegan, A. (2007). Managing human resources in the project-oriented company in "The Wiley Guide to Project Organizaiton \& Project Management Competencies": John Wiley \& Sons.

Ibrahim, A. R., Roy, M. H., Ahmed, Z., \& Imtiaz, G. (2010). An investigation of the status of the Malaysian construction industry. Benchmarking: An International Journal, 17(2), 294-308.

IPMA. (2006). ICB - IPMA Competence Baseline Version 3.0: International Project Management Association.

IPMA. (2015). ICB 4.0, Individual Competence Baseline for Project, Programme \& Portfolio Management Version 4.0

Netherlands: International Project Management Association.

Ismail, I. (2014). Faculty of Civil and Environmental Engineering.

Ismail, I., Memon, H. A., \& Abdul Rahman, I. (2013). Expert opinion on risk level for factors affecting time and cost overrun along the project lifecycle in Malaysian construction projects. International Journal of Construction Technology and Management, Vol.1(No.2).

Koops, L., Bosch-Rekveldt, M., Coman, L., Hertogh, M., \& Bakker, H. (2016). Identifying perspectives of public project managers on project success: Comparing viewpoints of managers from five countries in North-West Europe. International Journal of Project Management, 34(5), 874-889. doi:10.1016/j.ijproman.2016.03.007

Lechler, T. (2000). Empirical evidence of people as determinants of project success Projects as business constituents and guiding motives (pp. 217-227): Springer.

Loosemore, M., Dainty, A., \& Lingard, H. (2003). Human resource management in construction projects: Strategic and operational approaches: Taylor \& Francis.

Mantel, S. J., Meredith, J. R., Shafer, S. M., \& Sutton, M. M. (2006). Core Concepts: John Wiley \& Sons.

McKinlay, M. (2008). Where is Project Management running to...?(International Project Management Association, 22nd World Congress, Rome, 2008)[Electronic resource]. Paper presented at the The official website of the 22nd IPMA World Congress-Rome (Italy).

Michael, J., Deepak, T., Venishri, P., \& Siow, Y. T. (2014). Ranking the factors that influence the construction project management success - Malaysian Perspective. Civil and Environmental Research, 6(1). 
Ministry of Finance, M. (2017). 2018 Budget of Malaysia. Malaysia Retrieved from http://www.treasury.gov.my/pdf/budget/speech/bs18.pdf.

Morris, P. (2013). Reconstructing Project Management: John Wiley \& Sons.

Morris, P. W. G. (1997). The management of projects: Thomas Telford.

Muller, R., \& Turner, R. (2010). Leadership competency profiles of successful project managers. International Journal of Project Management, 28(5), 437-448. doi:10.1016/j.ijproman.2009.09.003

Mustafa Kamal, E., Haron, H. S., Md Ulang, N., \& Baharun, F. (2012). The critical review on the Malaysian construction industry. Journal of Economics and Sustainable Development, 3(13).

Nahod, M.-M., Vukomanović, M., \& Radujković, M. (2013). The Impact of ICB 3.0 Competences on Project Management Success. Procedia - Social and Behavioral Sciences, 74, $244-254$. doi:10.1016/j.sbspro.2013.03.014

Nie, Y. (2013). New KL budget terminal faces delay, cost overruns. The Straits Times, Newspaper, 8.

Nixon, P., Harrington, M., \& Parker, D. (2012). Leadership performance is significant to project success or failure: a critical analysis. International Journal of productivity and performance management, 61(2), 204-216.

Omidvar, G., Jaryani, F., Abdul Samad, Z., Zafarghandi, S. F., \& Nasab, S. S. (2011). A proposed framework for project managers' competencies and role of E-Portfolio to meet these competencies. International Journal of eEducation, e-Business, e-Management and e-Learning, Vol. 1(No. 4).

Pellegrinelli, S., \& Garagna, L. (2010). Facilitating selection and development: The case of the "Accidental Professionals" - Project and Programme Managers. Paper presented at the 2010 IPMA World Congress, Istanbul, Turkey.

Postma, T. (2016). Performance in Construction: The influence of middle management on the construction workers performance in production. (Master), Chalmers University of Technology, Sweden. Retrieved from http://publications.lib.chalmers.se/records/fulltext/244288/244288.pdf

Raja, J., Green, S., Leiringer, R., Dainty, A., \& Johnstone, S. (2013). Managing multiple forms of employment in the construction sector: implications for HRM. Human Resource Management Journal, 2013, 23(3), 313-328.

Ríos-Carmenado, I. d. 1., Díaz-Puente, J. M., \& Martínez-Almela, J. (2011). The effect that project management certification has on employability: agents' perceptions from Spain. Paper presented at the International Conference on Advances in Education and Management.

Russell, J. T., \& Chaudhury, P. D. (2008). Corporate social responsibility: what it means for the project manager.

Sambasivan, M., \& Soon, Y. W. (2007). Causes and effects of delays in Malaysian construction industry. International Journal of Project Management, 25(5), 517-526. doi:10.1016/j.ijproman.2006.11.007

Scott-Young, C., \& Samson, D. (2004). Project success and project team human resource management: evidence from capital projects in the process industries. Paper presented at the Proceedings of th PMI Research Conference, London.

Sekaran, U. (2003). Research Methods for Business: A Skill Building Approach (4th Edition ed.): John Wiley \& Sons.

Silvius, A. J. G., \& Schipper, R. (2012). Sustainability in project management competences. Procedia - Social and Behavioral Sciences.

Slevin, D. P., \& Pinto, J. K. (2007). An overview of behavioral issues in project management, in The Wiley Guide to Project Organizaiton \& Project Management Competencies (P. W. G. Morris \& J. K. Pinto Eds.). 
Sommerville, J., Craig, N., \& Hendry, J. (2010). The role of the project manager: all things to all people? Structural Survey, 28(2), 132-141. doi:10.1108/02630801011044235

Stewart, T. A. (1995). Planning a Career in a World without Managers. Fortune, 131(5), 72.

Toor, S.-u.-R., \& Ogunlana, S. (2006). Successful project leadership: understanding the personality traits and organizational factors. Paper presented at the Proceedings of CIB-W107, international symposium, construction in developing economies: new issues and challenges, Chile, Santiago.

Ullah, K., Abdullah, A. H., \& Nagapan, S. (2016). A framework for avoiding cost overruns in Malaysian construction projects. International Journal of Advanced and Applied Sciences, 3(3), 28 - 31.

Whiddett, S., \& Hollyforde, S. (2000). The competencies handbook.: London: CIPD.

Winch, G. M. (2010). Managing construction projects: John Wiley \& Sons.

Wolfson, A. D., Trebilcock, M. J., \& Tuohy, C. J. (1980). Regulating the professions: A theoretical framework. Occupational licensure and regulation, 180-214.

Wu, R. M. (2011). Profiling of project managers for project success (PhD), University of Phoenix.

Yong, Y. C., \& Mustafa, N. E. (2011). Clients consultants and contractors perception of critical success factors for construction projects in malaysia. Paper presented at the 27th Annual Association of Researchers in Construction Management, Bristol, UK.

Zwikael, O. (2009). Critical planning processes in construction projects. Construction Innovation, 9(4), 372-387. 